\title{
Adherence of Bacteria to Heart Valves In Vitro
}

\author{
Kenneth Gould, Carlos H. Ramirez-Ronda, Randall K. Holdies, and \\ JAY P. SANFORD \\ From the Departments of Internal Medicine and Microbiology, The University \\ of Texas Southwestern Medical School, Dallas, Texas 752.35
}

\begin{abstract}
A в S TRACT The abilities of 14 strains of aerobic gram-positive cocci and gram-negative bacilli to adhere in vitro to human or canine aortic valve leaflets were compared. 2-mm sections of excised valve leaflets were obtained by punch biopsy and were incubated under standardized conditions in suspensions of bacteria. Valve sections were subsequently washed and homogenized, and quantitative techniques were used to determine the proportions of bacteria from the initial suspensions that had adhered to the valve sections. Comparable results were obtained when these adherence ratios were determined by two independent methods based either on measurements of bacterial viability or of radioactivity in ${ }^{51} \mathrm{Cr}$-labeled bacteria. For each bacterial strain, the adherence ratio was constant over a wide range of concentrations of bacteria in the incubation medium. Strains of enterococci, viridans streptococci, coagulase-positive and coagulase-negative staphylococci and Pscudomonas aeruginosa (adherence ratios 0.003-0.017) were found to adhere more readily to valve sections than strains of Escherichia coli and Klebsiella pneumoniac (adherence ratios $0.00002-0.00004)$. The organisms that most frequently cause bacterial endocarditis were found to adhere best to heart valves in vitro, suggesting that the ability to adhere to valvular endothelium may be an important or essential characteristic of bacteria that cause endocarditis in man.
\end{abstract}

\section{INTRODUCTION}

Differences in the adherence of bacterial species or strains to mucous membranes have been shown to be important in determining the composition of the normal bacterial flora on mucosal surfaces $(1,2)$. Since colonization of specific mucosal surfaces is an early event in the pathogenesis of many bacterial infections (3), it is

These studies were presented in part before the Southern Section, American Federation for Clinical Research, New Orleans, La., January 1974.

Received for publication 28 June 19jt and in reised form 29 July 1975. likely that the ability or inability of a pathogenic bacterium to adhere to various mucosal surfaces is one important factor in determining the localization of infections caused by that organism. In addition, differences in adherence properties of bacterial pathogens may help to determine the most likely etiologic agents of infection at any particular anatomic site. Data comparing the adherence of aerobic gram-negative bacilli and of aerobic gram-positive cocci to specific mucosal surfaces are limited. In one study, Escherichia coli, a common cause of urinary tract infections, was found to adhere better to bladder mucosa than to tongue mucosa in experimental rats, while Streptococcus pyogenes, the etiologic agent of streptococcal pharyngitis, adhered more readily to rat tongue mucosa than to rat bladder mucosa (3).

In spite of an increasing incidence of gram-negative bacillary bacteremia (4), aerobic gram-positive cocci remain in the most frequently isolated bacteria associated with endocarditis in man $(5,6)$. Gram-negative bacillary endocarditis has remained unusual except in drug addicts $(7,8)$ and in prosthetic valve infections (9). The present study was undertaken to compare the ability of selected aerobic gram-positive cocci and gramnegative bacilli to adhere to the endothelial surfaces of human and canine aortic valve leaflets. Our data demonstrate that variations in adherence do occur and that the organisms that are more adherent to heart valves in vitro are the ones that most commonly cause bacterial endocarditis in man.

\section{METHODS}

Bactcrial strains. All of the bacterial strains used in this study were obtained from the microbiology laboratory of Parkland Memorial Hospital, Dallas, Tex. Except for three strains of viridans streptococci obtained from throat cultures, all gram-positive cocci were isolated from blood cultures of patients with bacterial endocarditis. All gramnegative bacilli were isolated from blood cultures of patients with bacteremia. Bacterial strains grown in trypticase soy broth $(\text { TSB })^{1}$ (Baltimore Biological Laboratories,

${ }^{1}$ Abbreitiations used in this paper: $\mathrm{CFU}$, colony-forming unit; I'BS, phosphate-buffered saline; TSB, trypticase soy broth. 
Baltimore, M(1.) were lyophilized in a 1:1 mixture of skim milk and TSB and were stored at $25^{\circ} \mathrm{C}$.

Preparation of standardized bacterial suspensions. Lyophilized cultures were rehydrated in $10 \mathrm{ml}$ of TSB and incubated overnight at $37^{\circ} \mathrm{C}$ in a $10 \% \quad \mathrm{CO}_{2}$ atmosphere without agitation. $10-\mathrm{ml}$ samples from the overnight cultures were centrifuged at $12,000 \mathrm{~g}$ for $10 \mathrm{~min}$. The bacteria in the pellet were washed twice by suspension in $10-\mathrm{ml}$ samples of $\mathrm{pH} 7.2$ phosphate-buffered saline solution (PBS) $\left(\mathrm{NaCl}, 122.4 \mathrm{~g} ; \mathrm{Na}_{2} \mathrm{HPO}_{4}, 26.64 \mathrm{~g} ; \mathrm{KH}_{2} \mathrm{PO}_{4}, 7.75 \mathrm{~g}\right.$; distilled water, 19 liters) followed by centrifugation, and the washed bacteria were resuspended in $10-\mathrm{ml}$ samples of PBS. Clumped bacteria were dispersed by aspirating and ejecting each suspension three times through a sterile 25 gauge needle attached to a hypodermic syringe. Residual bacterial clumps were then removed by filtering the suspensions through $8-\mu \mathrm{m}$ membrane filters (Nuclepore Corp., Pleasanton, Calif.). Wet mounts of the filtered bacterial suspensions were examined microscopically to confirm that the suspensions contained primarily single bacterial cells. The absorbance of each suspension was measured at 590 $\mathrm{nm}$, and standardized suspensions were prepared with $\mathrm{A}_{500}=$ 0.3 . The number of viable bacteria in each standardized suspension was determined by plating duplicate $0.10-\mathrm{ml}$ samples from 10-fold serial dilutions of the suspension on trypticase soy agar (Baltimore Biological Laboratories). Plates were incubated at $37^{\circ} \mathrm{C}$ in a $10 \% \quad \mathrm{CO}_{2}$ atmosphere for $18 \mathrm{~h}$, and bacterial colonies were enumerated. Viable counts for the original suspensions were calculated from the observed colony counts and the known dilution factors. When lesser concentrations of bacteria were desired, appropriate dilutions were made from the standardized suspensions.

Radioisotopic labeling of bacteria. The procedure for labeling of bacteria with ${ }^{51} \mathrm{Cr}$ was a modification of a published method (10). $250 \mu \mathrm{Ci}$ of $\mathrm{Na}^{51} \mathrm{CrO}_{4}(363 \mathrm{mCi} / \mathrm{mg}$, New England Nuclear, Boston, Mass.) was added to $10-\mathrm{ml}$ samples of standardized bacterial suspensions with an absorbance of 0.3 . The suspensions were incubated at $37^{\circ} \mathrm{C}$ for $3 \mathrm{~h}$, centrifuged at $12,000 \mathrm{~g}$ for $10 \mathrm{~min}$, and then washed three times with cold PBS. The ${ }^{51} \mathrm{Cr}$-labeled bacteria were resuspended in $10 \mathrm{ml}$ of cold PBS. Bacterial clumps were eliminated by the same dispersion and filtration procedures described above, and suspensions of the ${ }^{51} \mathrm{Cr}$-labeled bacteria with an absorbance of 0.3 were prepared. $1-\mathrm{ml}$ samples from the ${ }^{51} \mathrm{Cr}$-labeled bacterial suspensions were passed through $0.45-\mu \mathrm{m}$ membrane filters (Millipore Corp., Bedford, Mass.), and the radioactivity associated with the filters and with the filtrates was measured to determine the percentage of the ${ }^{51} \mathrm{Cr}$ label in the suspensions that was firmly bound to the bacteria.

Preparation of aortic vali'e leafet sections. In experiments utilizing canine valves, hearts were excised from heparinized dogs sacrificed for other purposes. Human aortic valves were obtained from four cadavers during autopsies performed by the Dallas County Medical Examiner's Office. The aortic valve leaflets were removed with sterile technique and were placed into sterile PBS solution, and subsequent procedures were done with sterile technique at $25^{\circ} \mathrm{C}$. The valve leaflets were removed from the saline solution and placed on a mat consisting of five pieces of filter paper. Circular sections of aortic valve with a 2 -mm diameter were made by punch biopsy of the leaflets utilizing a Keyes punch (105-985, George Tiemann Enterprises, Inc., Long Island City, N. Y.) designed for biopsying skin, and these sections were placed in PBS.
Quantitatic'e measurement of hacterial adhorence to zalie sections. Four valve sections were placed in 3-ml samples of ${ }^{51} \mathrm{Cr}$-labeled or unlabeled suspensions of bacteria in $50 \times$ 12-mm "box-type" plastic petri dishes (Falcon Plastics, Oxnard, Calif.), and were agitated at $160 \mathrm{cycles} / \mathrm{min}$ on a reciprocating shaker at room temperature. After $1 \mathrm{~h}$, the four valve sections were removed from the suspensions, and two were placed into each of two $60 \times 15-\mathrm{mm}$ plastic petri dishes with $3-\mathrm{ml}$ samples of PBS. The pairs of valve sections were washed by swirling for $15 \mathrm{~s}$ and were transferred to similar dishes for two further washes. Each pair of valve sections was then placed into a mortar with $3 \mathrm{ml}$ of PBS and approximately $0.5 \mathrm{~g}$ of sterile sand and was homogenized with a pestle until discrete pieces of tissue were no longer visible.

Quantitation of viable bacteria was performed by removing $1.0-\mathrm{ml}$ samples of the original bacterial suspensions and of the homogenized valve sections, diluting serially in PBS, plating $0.1-\mathrm{ml}$ samples of appropriate dilutions on trypticase soy agar, and counting colonies after overnight incubation in a $10 \% \quad \mathrm{CO}_{2}$ atmosphere at $37^{\circ} \mathrm{C}$. Quantitation of ${ }^{51} \mathrm{Cr}$ labeled bacteria was performed by comparing the radioactivity in $1-\mathrm{ml}$ samples of the original bacterial suspensions and of the homogenized valve sections. Counting was performed in a Packard model 578 gamma scintillation spectrometer (Packard Instrument Co., Inc., Downers Grove, III.).

The "adherence ratio" was defined as the proportion of bacteria in the initial suspension that was recovered from the washed, homogenized aortic valve sections. Experimental determinations of adherence ratios were based either on viable counts or on measurements of radioactivity in ${ }^{51} \mathrm{Cr}$ labeled bacteria and were calculated by the following formulas: adherence ratio $=$ (viable bacteria recovered from heart valves $[\mathrm{CFU} / \mathrm{ml}]) /($ viable bacteria in incubation media $[\mathrm{CFU} / \mathrm{ml}]$ ) and adherence ratio $=$ (radioactivity adsorbed to heart valves $[\mathrm{cpm} / \mathrm{ml}]) /($ radioactivity in incubation medium $[\mathrm{cpm} / \mathrm{ml}])$, where CFU represents colonyforming units.

\section{RESULTS}

Interpretation of our studies on the adherence of various bacterial strains to sections of aortic valve leaflets is dependent upon the results of a number of control experiments that will be described before the results of the adherence studies.

Role of bacterial clumping. Apparent differences in adherence between gram-positive cocci and gram-negative bacilli might be the result of a greater tendency for gram-positive cocci to clump or to cluster. Although clumps containing multiple organisms produce single colonies upon culture, they might have a greater probability than single bacteria of adhering to aortic valve sections. This possibility was excluded by examining the standardized bacterial suspensions by light microscopy and demonstrating that they consisted almost completely of single unaggregated bacteria.

Radioisotopic labeling of bacteria with ${ }^{51} \mathrm{Cr}$. To demonstrate that the ${ }^{51} \mathrm{Cr}$ was firmly attached to the bacteria, 1.0 -ml samples of the ${ }^{51} \mathrm{Cr}$-labeled bacterial suspensions were passed through $0.45-\mu \mathrm{m}$ membrane filters, and the 
TABLE I

Radioisotopic Labeling of Bacteria with $\mathrm{Na}^{51} \mathrm{CrO}_{4}{ }^{*}$

\begin{tabular}{lcccc}
\hline \multicolumn{1}{c}{ Bacterial strain } & $\begin{array}{c}\text { Radioactivity of } \\
\text { 51Cr-labeled } \\
\text { bacterial } \\
\text { suspension }\end{array}$ & $\begin{array}{c}\text { Radioactivity } \\
\text { retained on } \\
\text { filter }\end{array}$ & $\begin{array}{c}\text { Radioactivity } \\
\text { in filtrate }\end{array}$ & $\begin{array}{c}\text { Radioactivity } \\
\text { bound to } \\
\text { bacteria }\end{array}$ \\
\hline Enterococcus KG3 & $c p m / m l$ & $c p m$ & $c p m / m l$ & $\%$ \\
Viridans streptococcus 6090 & 483,000 & 469,700 & 23,700 & 95.5 \\
S. aureus G4 & 213,060 & 210,602 & 4,533 & 95.3 \\
S. epidermidis 6725 & 115,400 & 109,500 & 7,000 & 94.0 \\
P. aeruginosa 6042 & 218,900 & 200,900 & 13,800 & 93.7 \\
E. coli 7165 & 857,200 & 800,900 & 51,300 & 94.0 \\
K. pneumoniae 8194 & 713,400 & 695,800 & 20,680 & 97.5 \\
\hline
\end{tabular}

* Bacteria were labeled with $\mathrm{Na}^{51} \mathrm{CrO}_{4}$, washed, and resuspended in PBS as described in Methods. 1 -ml samples of the suspensions of ${ }^{51} \mathrm{Cr}$-labeled bacteria were passed through $0.45-\mu \mathrm{m}$ filters, and measurements were made of the radioactivity in the filtrates and on the filters.

bacterial-associated radioactivity retained on the filters was compared with the radioactivity in the filtrates (Table I). More than $93 \%$ of the radioactivity was bound to the bacteria with each bacterial strain tested. To determine if the small amounts of radioactivity that leached from the bacteria could effectively bind to the sections of aortic valve leaflets, the cell-free culture filtrates from the ${ }^{51} \mathrm{Cr}$-labeled bacterial suspensions were incubated with sections of aortic valve leaflets, and the usual procedures of washing, grinding, sampling, and counting were followed (Table II). Less than $0.5 \%$ of the free ${ }^{51} \mathrm{Cr}$ was bound to the valve leaflets. The expected background due to adsorption by heart valves of free ${ }^{51} \mathrm{Cr}$ in suspensions of ${ }^{51} \mathrm{Cr}$-labeled bacteria should therefore not exceed $0.035 \%$ of the total radioactivity present in the suspensions.

TABLE II

Adsorption by Aortic Valve Leaflets of Free $\mathrm{Na}^{51} \mathrm{CrO}_{4}$ from Suspensions of ${ }^{51} \mathrm{Cr}$-Labeled Bacteria*

\begin{tabular}{|c|c|c|c|}
\hline Culture filtrate & $\begin{array}{c}\text { Radio- } \\
\text { activity } \\
\text { in cell-free } \\
\text { culture } \\
\text { filtrate }\end{array}$ & $\begin{array}{c}\text { Radio- } \\
\text { activity } \\
\text { adsorbed } \\
\text { to valve } \\
\text { sections }\end{array}$ & $\begin{array}{c}\text { Free } \\
\mathrm{Na}^{51} \mathrm{CrO} \\
\text { adsorbed } \\
\text { to valve } \\
\text { sections }\end{array}$ \\
\hline & \multicolumn{2}{|c|}{$c p m / m l$} & $\%$ \\
\hline Enterococcus KG3 & 36,000 & 182 & 0.5 \\
\hline Viridans streptococcus 6090 & 5,100 & 15 & 0.3 \\
\hline S. aureus G4 & 8,070 & 34 & 0.4 \\
\hline S. epidermidis 6725 & 8,758 & 21 & 0.2 \\
\hline$P$. aeruginosa 6042 & 42,900 & 172 & 0.4 \\
\hline E. coli 7165 & 31,500 & 126 & 0.4 \\
\hline K. pneumoniae 8194 & 20,520 & 82 & 0.3 \\
\hline
\end{tabular}

* Suspensions of ${ }^{51} \mathrm{Cr}$-labeled bacteria were filtered through $0.45-\mu \mathrm{m}$ membrane filters, and the cell-free filtrates were incubated with sections of aortic valve leaflets. The radioactivity adsorbed to the sections of valve leaflets was determined after washing and homogenizing them as described in Methods.
Influence of grinding on the viability of bacteria. Apparent differences in adherence of various bacterial strains to valve leaflets might also result from differential killing of the bacteria during homogenization of the valve sections by grinding with sand in a mortar and pestle. Viable counts of representative bacterial strains were measured in control experiments both before and after subjecting samples of standardized bacterial suspensions to the grinding procedure, and no killing was observed. This possible variable was also controlled by the use of radioisotopically labeled bacteria, since detection of the radioactivity in ${ }^{51} \mathrm{Cr}$-labeled bacteria adsorbed to the valve sections should be independent of changes in bacterial viability during the grinding procedure.

Susceptibility of bacterial strains to serum. Although the experiments were performed with sections of aortic valve leaflets suspended in PBS solution, it was conceivable that traces of serum on the valves might have contributed to the killing of certain susceptible bacterial strains, resulting in apparent differences in adsorption between bacterial strains. Representative strains were studied for their susceptibility to the bactericidal effects of fresh canine and human serum as well as to heatinactivated $\left(56^{\circ} \mathrm{C}\right.$ for $\left.30 \mathrm{~min}\right)$ serum as a control. None of the strains utilized in our experiments was "serum sensitive" (Table III).

Site of bacterial adherence to the valve sections. Since the area of the two endothelial surfaces of the valve sections is extremely large in comparison to the area of the cut edge, it seemed likely that the adherence observed was the consequence of attachment of bacteria to the endothelialized surfaces rather than to the cut edge. To confirm this, valve sections were incubated with bacteria, washed, stained with methylene blue, and observed by light microscopy. Most of the bacteria 
TABLE III

Susceptibility of Bacterial Strains to Serum

\begin{tabular}{|c|c|c|c|c|}
\hline \multirow[b]{2}{*}{ Serum } & \multirow[b]{2}{*}{ Bacterial strain } & \multirow[b]{2}{*}{$\begin{array}{l}\text { Original } \\
\text { inoculum }\end{array}$} & \multicolumn{2}{|c|}{ Viable bacteria } \\
\hline & & & Normal serum & $\begin{array}{c}\text { Heat-inactivated } \\
\text { serum }\end{array}$ \\
\hline & & $C F U / m l^{*}$ & \multicolumn{2}{|c|}{$C F U / m l$ after $24 h$} \\
\hline \multirow[t]{3}{*}{ Canine } & Enterococcus KG3 & 285 & $>10^{9}$ & $>10^{9}$ \\
\hline & $P$. aeruginosa 8734 & 170 & $>10^{9}$ & $>10^{9}$ \\
\hline & E. coli 6662 & 360 & $>10^{9}$ & $>10^{9}$ \\
\hline \multirow[t]{7}{*}{ Human } & Enterococcus KG3 & 148 & $>10^{9}$ & $>10^{9}$ \\
\hline & Viridans streptococcus 6090 & 174 & $>10^{9}$ & $>10^{9}$ \\
\hline & S. aureus G4 & 175 & $>10^{9}$ & $>10^{9}$ \\
\hline & S. epidermidis 6725 & 134 & $>10^{9}$ & $>10^{9}$ \\
\hline & $P$. aeruginosa 6042 & 190 & $3.3 \times 10^{8}$ & $3.6 \times 10^{8}$ \\
\hline & E. coli 7165 & 260 & $5.5 \times 10^{8}$ & $6.4 \times 10^{8}$ \\
\hline & K. pneumoniae 8194 & 210 & $>10^{9}$ & $>10^{9}$ \\
\hline
\end{tabular}

* CFU, colony-forming units.

were seen to adhere to both endothelial surfaces, with only a few organisms adhering along the cut edge of the valve sections. Although quantitative measurements of adherence could not be performed by this method, these observations confirmed the hypothesis that the bacteria were adhering primarily to the endothelial surfaces of the aortic valve sections.

Conditions influencing bacterial adherence. In preliminary experiments, no differences were observed in the ability of individual bacterial strains to adhere to sections of aortic valve leaflets obtained from human or canine aortic valves. For convenience, canine valves were utilized for most of the studies reported here. Adherence was facilitated by agitation of the valve sections in the bacterial suspension, and very low levels of adherence were observed when valve sections were incubated in bacterial suspensions without agitation. The adherence ratios for representative bacterial strains were similar whether incubation was carried out in PBS or in fresh human or canine serum (Table IV). For this reason, most of the studies were performed utilizing PBS.

Relationship of adherence to concentration of bacteria in the incubation medium. For each bacterial strain tested, the number of bacteria that became attached to aortic valve sections was a constant proportion of the number of bacteria in the incubation medium. Representative data for a strain of enterococcus (KG3) are presented in Table V. The observed adherence ratio was similar whether calculated from viable bacterial counts or from measurements of radioactivity in the ${ }^{81} \mathrm{Cr}$-labeled enterococci. The adherence ratio was constant over a 10,000 -fold range in the concentration of bacteria in the incubation medium. Linearity between the initial concentration of bacteria in the incubation medium and the number of bacteria adhering to standard size valve sections was observed for each of the bacterial strains tested (Fig. 1).

Differences in adherence characteristics of various bacterial strains and species. Comparison of adherence ratios for various bacterial strains reveals striking differences (Table VI). The strains of gram-positive cocci, including enterococci, viridans streptococci, and both coagulase-positive and coagulase-negative staphylococci, were found to have a much greater probability of adhering to aortic valve sections than did the strains of Klebsiella pneumoniae or E. coli. In contrast to the strains of Enterobacteriaceae, the adherence ratios of strains of Pseudomonas aeruginosa were comparable to those of the gram-positive cocci.

\section{DISCUSSION}

The adherence of various bacteria to the surface of heart valves was studied for two reasons. First, the attach-

TABLE IV

Comparison of Bacterial Adherence to Aortic Valie Leaflets in Serum and in PBS Solution

\begin{tabular}{|c|c|c|c|c|}
\hline \multirow[b]{3}{*}{ Bacterial strain } & \multicolumn{4}{|c|}{ Adherence ratio, $\times 10^{5 *}$} \\
\hline & \multicolumn{2}{|c|}{ Incubation in PBS } & \multicolumn{2}{|c|}{$\begin{array}{l}\text { Incubation in human } \\
\text { serum }\end{array}$} \\
\hline & $\begin{array}{l}\text { Viable } \\
\text { counts }\end{array}$ & $\begin{array}{l}\text { Isotopic } \\
\text { label }\end{array}$ & $\begin{array}{l}\text { Viable } \\
\text { counts }\end{array}$ & $\begin{array}{l}\text { Isotopic } \\
\text { label }\end{array}$ \\
\hline Enterococcus KG3 & 1,300 & 1,690 & 1,610 & 1,640 \\
\hline$P$. aeruginosa 8734 & 368 & 366 & 485 & 437 \\
\hline E. coli 6662 & 1.86 & 1.84 & 1.96 & 1.97 \\
\hline
\end{tabular}

* Adherence ratios were calculated as described in Methods. 
TABLE V

Relationship between Concentration of Bacteria in the Incubation Medium and Adherence Ratios for Enterococcus KG3

\begin{tabular}{|c|c|c|c|c|c|}
\hline $\begin{array}{l}\text { Bacteria in } \\
\text { incubation } \\
\text { medium }\end{array}$ & $\begin{array}{l}\text { Bacteria adherent } \\
\text { to valve sections }\end{array}$ & $\begin{array}{l}\text { Adherence ratio } \\
\left(\times 10^{5}\right) \text { calculated } \\
\text { from viable counts* }\end{array}$ & $\begin{array}{l}\text { Radioactivity in } \\
\text { incubation } \\
\text { medium }\end{array}$ & $\begin{array}{l}\text { Radioactivity } \\
\text { adherent to } \\
\text { valve sections }\end{array}$ & $\begin{array}{l}\text { Adherence ratio } \\
\left(\times 10^{5}\right) \text { calculated } \\
\text { from isotopic label* }\end{array}$ \\
\hline$C F U / m l$ & $C F U / m l$ & & $c p m ; m l$ & $c p m ; m l$ & \\
\hline $4.0 \times 10^{8}$ & $5.2 \times 10^{6}$ & 1,300 & 499,600 & 6,888 & 1,390 \\
\hline $3.4 \times 10^{8}$ & $5.7 \times 10^{6}$ & 1,690 & 483,000 & 8,065 & 1,690 \\
\hline $3.9 \times 10^{7}$ & $5.0 \times 10^{5}$ & 1,260 & 49,413 & 635 & 1,300 \\
\hline $4.1 \times 10^{6}$ & $5.4 \times 10^{4}$ & 1,320 & 5,158 & 67 & 1,320 \\
\hline $2.9 \times 10^{6}$ & $4.7 \times 10^{4}$ & 1,520 & 4,150 & 64 & 1,560 \\
\hline $3.9 \times 10^{5}$ & $5.0 \times 10^{3}$ & 1,280 & - & - & - \\
\hline $3.9 \times 10^{4}$ & $5.9 \times 10^{2}$ & 1,520 & - & - & - \\
\hline $3.9 \times 10^{4}$ & $5.2 \times 10^{2}$ & 1,350 & - & - & - \\
\hline - & - & $\begin{array}{c}1,400 \pm 54 \\
(\text { Mean } \pm \text { SEM })\end{array}$ & - & - & $\begin{array}{c}1,+50 \pm 77 \\
(\text { Mean } \pm \text { SEM })\end{array}$ \\
\hline
\end{tabular}

* Adherence ratios were calculated as described in Methods.

ment of bacteria to heart valves may be the initial event in the pathogenesis of bacterial endocarditis; and, second, there is a great discrepancy in the prevalence of naturally occurring endocarditis produced by aerobic gram-positive and gram-negative bacteria (5-8). It seemed reasonable, therefore, to determine experimentally whether there are significant differences in the ability of aerobic gram-positive and gram-negative bac-
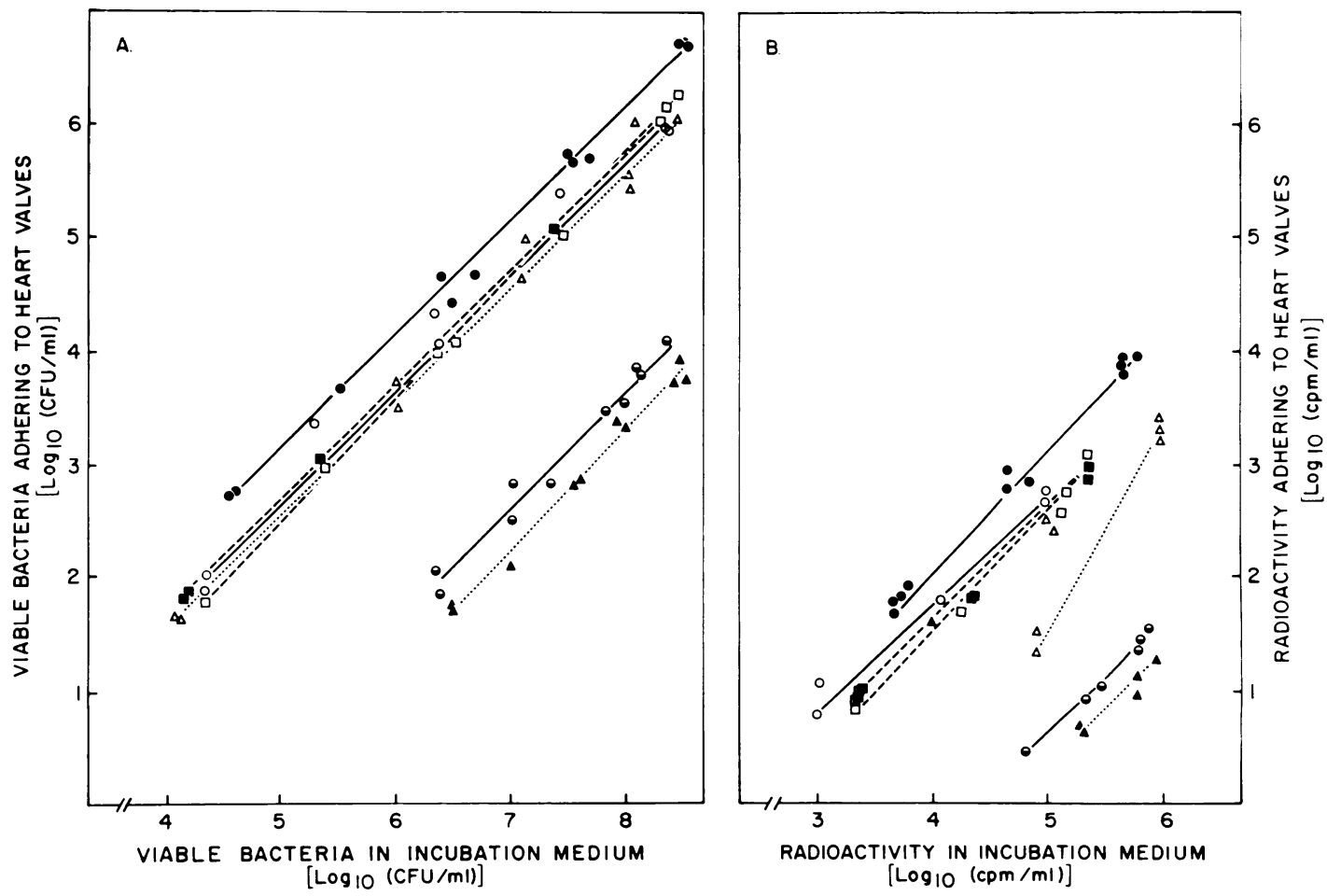

Figure 1 Relationship between concentration of bacteria in the incubation medium and adherence of selected bacterial strains: (A) viable counts, (B) radioactivity. Data obtained with individual strains of bacteria from each bacterial species or group were similar and are represented by similar symbols in this figure. (๑), enterococci KG3, G2, and G5; (O), S. aureus G4; ( $), S$. epidermidis $6725 ;(\square)$, viridans streptococci 6090,4046 , and 4024;

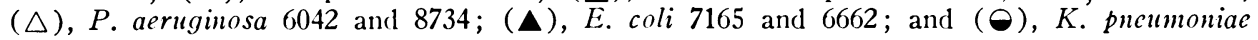
8194 and 8713. 
TABLE VI

Adherence of Selected Bacterial Strains to Aortic Valie Leaflets

\begin{tabular}{|c|c|c|c|c|}
\hline Bacterial strain & $\begin{array}{l}\text { Number of } \\
\text { observations }\end{array}$ & $\begin{array}{l}\text { Adherence ratio } \\
\left(\times 10^{5}\right) \text { calculated } \\
\text { from viable counts* }\end{array}$ & $\begin{array}{l}\text { Number of } \\
\text { observations }\end{array}$ & $\begin{array}{l}\text { Adherence ratio } \\
\left(\times 10^{5}\right) \text { calculated } \\
\text { from isotopic label* }\end{array}$ \\
\hline & & mean $\pm S E . M$ & & mean $\pm S E .1 I$ \\
\hline Enterococcus KG3 & 8 & $1,400 \pm 54$ & 5 & $1,450 \pm 77$ \\
\hline Enterococcus KG2 & 3 & $1,750 \pm 120$ & 3 & $1,730 \pm 125$ \\
\hline Enterococcus G5 & 3 & $1,410 \pm 85$ & 3 & $1,280 \pm 110$ \\
\hline Viridans streptococcus 4024 & 4 & $347 \pm 14$ & 3 & $325 \pm 3$ \\
\hline Viridans streptococcus 6090 & 3 & $552 \pm 82$ & 3 & $691 \pm 38$ \\
\hline Viridans streptococcus 4046 & 4 & $379 \pm 15$ & 3 & $408 \pm 40$ \\
\hline S. aureus G4 & 8 & $533 \pm 52$ & 5 & $579 \pm 61$ \\
\hline S. epidermidis 6725 & 8 & $454 \pm 38$ & 5 & $459 \pm 56$ \\
\hline P. aeruginosa 6042 & 8 & $305 \pm 25$ & 5 & $324 \pm 36$ \\
\hline P. aeruginosa 8734 & 3 & $378 \pm 10$ & 3 & $379 \pm 11$ \\
\hline E. coli 7165 & 7 & $2.0 \pm 0.2$ & 3 & $2.2 \pm 0.4$ \\
\hline E. coli 6662 & 3 & $2.0 \pm 0.2$ & 2 & $2.1 \pm 0.2$ \\
\hline$K$. pneumoniae 8194 & 7 & $4.2 \pm 0.4$ & 4 & $4.5 \pm 0.3$ \\
\hline K. pneumoniae 8713 & 3 & $4.5 \pm 0.3$ & 2 & $4.2 \pm 0.4$ \\
\hline
\end{tabular}

* Adherence ratios were calculated as described in Methods.

teria to attach to the endothelial surface of heart valves. In our model, we have been able to demonstrate such differences and have shown that the organisms that most commonly cause bacterial endocarditis in man also adhere more readily to sections of heart valves in vitro. This correlation suggests that the ability to adhere to heart valves may be an important or an essential characteristic of bacteria that cause endocarditis.

In previous studies of adherence of bacteria to mucosal or other surfaces, components of the surface of bacterial cells have been shown to be important in determining their ability to adhere. The presence of pili on gonococci correlates with adherence and with pathogenicity (11), and both capsular polysaccharides (12) and $\mathrm{M}$ proteins (13) produced by streptococci are important determinants of their ability to adhere to specific surfaces. Coating of streptococci with secretory IgA antibody has been shown to decrease their ability to adhere to rat oral mucosa (14), and the presence of coproantibody against Vibrio cholerae can protect rabbits from experimental cholera, possibly by decreasing the ability of $V$. cholerae to adhere to small bowel mucosa (15). These observations demonstrate that cell surface components of bacteria can determine adherence, and it is likely that receptors on the surface of mammalian cells are also involved in such adherence phenomena.

Although it seems likely that the initial event in the pathogenesis of bacterial endocarditis is the attachment of bacteria to heart valves, little is known concerning the specific components of either the bacteria or the heart valves that are involved in adherence. Our data suggest that the endothelial surface of normal heart valves has receptors that can interact with and bind to surface components of specific pathogenic bacteria such as enterococci, Staphylococcus aureus, and viridans streptococci (Table VI). Since adherence in vitro occurs equally well in serum and in buffered saline solution (Table IV), it is probable that adherence of the type we have demonstrated can also occur in vivo. The adherence ratios for each bacterial strain tested were shown to remain constant with different concentrations of bacteria in the incubation medium (Table V and Fig. 1). If a similar relationship holds true in vivo, then the number of bacteria adhering to heart valves should be directly proportional to the number of bacteria circulating in the blood. Thus, the probability of bacterial colonization of heart valves should be related to the duration and to the magnitude of bacteremia as well as to the ability of the bacteria to adhere to the heart valves.

In addition to the possibility that normal valvular endothelium has receptors for specific bacteria, other investigators have considered the hypothesis that bacterial colonization of heart valves occurs on thrombi $(16,17)$. Adherence of various bacteria to thrombi has not been systematically investigated. It is interesting to speculate that bacterial adherence to thrombi on pathologically altered valves might be particularly important in the pathogenesis of subacute bacterial endocarditis in man (16) or in experimental endocarditis in rabbits (18), while 
adherence to normal valvular endothelium might be of greater significance in the development of acute bacterial endocarditis in the absence of known preexisting valvular pathology.

Although all bacterial strains from cases of endocarditis adhered well to sections of heart valves in vitro in our experiments, such adherence is not the only determinant of bacterial virulence in endocarditis. This is clearly demonstrated by the observation that $P$. aeruginosa and Staphylococcus epidermidis, which rarely cause endocarditis in man, both adhered well to heart valve sections. The ability of bacteria to multiply in vivo and to survive in the presence of normal host defenses is also of great importance. However, the fact that we have demonstrated a relatively high level of adherence for $P$. aeruginosa in our model might help to explain the selection of $P$. aeruginosa as the gram-negative organism showing the greatest association with endocarditis in the addict population $(7,8)$.

In summary, we were able to show that bacteria adhere in vitro to sections prepared from human and canine aortic valve leaflets and that the quantitative measurement of adherence was reproducible for each bacterial strain tested. We have used this technique to demonstrate striking differences in adherence of various bacterial strains. Specifically, enterococci, staphylococci, and streptococci were shown to be more adherent than Enterobacteriaceae such as $K$. pneumoniae and $E$. coli. $P$. aeruginosa adhered as well as the staphylococci and the streptococci, but not as well as the enterococci.

\section{ACKNOWLEDGMENTS}

We thank James Wallace for technical assistance.

This work was supported by Training grant 5 T01 AI 00030 from the National Institute of Allergy and Infectious Diseases, National Institutes of Health.

\section{REFERENCES}

1. Gibbons, R. J., and J. van Houte. 1971. Selective bacterial adherence to oral epithelial surfaces and its role as an ecological determinant. Infect. Immun. 3: 567573.

2. Van Houte, J., R. J. Gibbons, and A. J. Pulkkinen. 1971. Adherence as an ecological determinant for streptococci in the human mouth. Arch. Oral Biol. 16: 11311141 .
3. Ellen, R. P., and R. J. Gibbons. 1974. Parameters affecting the adherence and tissue tropisms of Streptococcus pyogenes. Infect. Immun. 9: 85-91.

4. McHenry, M. C., W. J. Martin, and W. E. Wellman. 1962. Bacteremia due to gram-negative bacilli. Review of 113 cases encountered in five-year period 1955 through 1959. Ann. Intern. Med. 56: 207-219.

5. Lerner, P. I., and L. Weinstein. 1966. Infective endocarditis in the antibiotic era. N. Engl. J. Med. 274: 259-266.

6. Finland, M., and M. W. Barnes. 1970. Changing etiology of bacterial endocarditis in the antibacterial era. Experiences at Boston City Hospital 1933-1965. Ann. Intern. Med. 72 : 341-348.

7. Cherubin, C., M. Baden, F. Kavaler, S. Lerner, and W. Cline. 1968. Infective endocarditis in narcotic addicts. Ann. Intern. Med. 69: 1091-1098.

8. Reyes, M. P., W. A. Palutke, R. F. Wylin, and A. M. Lerner. 1973. Pseudomonas endocarditis in the Detroit Medical Center 1969-1972. Medicine (Baltimore). 52: 173-194.

9. Wilson, W. R., P. M. Jaumin, G. K. Danielson, E. R. Giuliani, J. A. Washington, II, and J. E. Geraci. 1975. Prosthetic valve endocarditis. Ann. Intern. Med. 82: 751-756.

10. Fierer, J., F. Finley, and A. I. Braude. 1974. Release of ${ }^{51} \mathrm{Cr}$-endotoxin from bacteria as an assay of serum bactericidal activity. J. Immunol. 112: 2184-2192.

11. Punsalang, A. P., Jr., and W. D. Sawyer. 1973. Role of pili in the virulence of Neisseria gonorrhoeae. Infect. Immun. 8: 255-263.

12. Mukasa, H., and H. D. Slade. 1973. Mechanism of adherence of Streptococcus muians to smooth surfaces. I. Roles of insoluble dextran-levan synthetase enzymes and cell wall polysaccharide antigens in plaque formation. Infect. Immun. 8: 555-562.

13. Ellen, R. P., and R. J. Gibbons. 1972. M protein-associated adherence of Streptococcus pyogenes to epithelial surfaces. Prerequisite for virulence. Infect. Immun. 5: 826-830.

14. Williams, R. C., and R. J. Gibbons. 1972. Inhibition of bacterial adherence by secretory immunoglobulin A: a mechanism of antigen disposal. Science (Wash. D. C.). 177: 697-699.

15. Freter, R. 1972. Parameters affecting the association of vibrios with the intestinal surface in experimental cholera. Infect. Immun. 6: 134-141.

16. Angrist, A., M. Oka, and K. Nakao. 1967. Vegetative endocarditis. Pathol. Annu. 2: 155-212.

17. Angrist, A. A., and M. Oka. 1963. Pathogenesis of bacterial endocarditis. JAMA (J.Am. Med. Assoc.). 183: 249-252.

18. Durack, D. T., and P. B. Beeson. 1972. Experimental bacterial endocarditis. I. Colonization of a sterile vegetation. Br. J. Exp. Pathol. 53: 44-49. 